\title{
Lokun í botn- og hryggslagæð heila Sjúkratilfelli og yfirlit
}

\section{Albert Páll Sigurðsson¹ læknir \\ Porsteinn Gunnarsson²,3 læknir \\ Hjalti Már Pórisson ${ }^{3}$ læknir \\ Ingvar Hákon Ólafsson ${ }^{4}$ læknir \\ Gunnar Björn Gunnarsson ${ }^{5}$ læknir}

${ }^{1}$ Taugadeild Landspítala Fossvogi, ${ }^{2}$ röntgendeild Sahlgrenska-sjúkrahússins, Gautaborg, Svípjóð, inngripsröntgen- og æðapræðingardeild Landspítala, ${ }^{4}$ heila- og taugaskurðlækningadeild Landspítala, ${ }^{5}$ endurhæfingardeild Landspítala Grensási.

Fyrirspurnum svarar Albert Páll Sigurðsson, alberts@landspitali.is

Höfundar fengu sampykki sjúklings fyrir pessari umfjöllun og birtingu.

\section{Inngangur}

Greinar um sega í botn- og hryggslagæðum heila voru lesnar auk greina sem fjölluðu um myndgreiningar, blóðpynningu, segaleysandi meðferð, framskyggna skráningarannsókn, fjarheilbrigðipjónustu, segabrottnám og meðferð við illvígu drepi í heila. Greinar voru valdar með tilliti til mikilvægis og pýðingar fyrir ritun pessarar yfirlitsgreinar. Leitin takmarkaðist við texta á ensku og pýsku.

Farið er yfir klíníska pætti lokana í botn- og hryggslagæðum heila, notkun og notagildi myndgreininga og meðferðar (blóðpynning, segaleysandi meðferð í bláæð og slagæð) sem hafa verið reyndar. Að lokum er lýst notagildi segabrottnáms og aðgerðar við illvígu drepi í heila við pessar kringumstæður.

\section{Sjúkratilfelli}

22 ára rétthent kona var flutt á bráđamóttöku Landspítala sumarið 2018. Hún hafði verið hraust en nokkrum dögum áður hafði hún fundið fyrir höfuðverk og slappleika. Hún fór pví ekki í vinnu á innlagnardegi. Eiginmaður hennar kom heim milli kl. 17-18, en pá hafði konan kastað upp og var með skerta meðvitund. Kallaður var til sjúkrabíll. Lífsmörk og blóðsykur voru innan eðlilegra marka og engin merki um áverka. Í sjúkrabíl fékk hún 2,5 mg af

\section{Á G R I P}

Hér er lýst sjúkratilfelli 22 ára gamallrar hraustrar konu sem komið var með meðvitundarlausa á bráðamóttöku Landspítala sumarið 2018. Tölvusneiðmynd af heila við komu sýndi stórt drep í litla heila hægra megin og mikinn bjúg sem prengdi að fjórða heilahólfi. đEðamynd við komu vakti grun um flysjun í vinstri hryggslagæð og lokun botnslagæðar sem var staðfest síðar við innæðameðferð. Hafin var segaleysandi meðferð en síðan farið í segabrottnám og fékkst góð enduropnun æðar. Daginn eftir fór hún í skurðaðgerð vegna illvígs dreps í litla heila. Henni farnaðist vel og skoraði 1 stig á endurbættum Rankin-kvarða 90 dögum eftir úrskrift af sjúkrahúsi. midazolam og vökva í æð auk pess sem öndunarvegir voru hreinsaðir.

Við nánari eftirgrennslan á bráđamóttöku kom í ljós að hún hafði verið slöpp og kastað upp dagana fyrir komu. Hún hafði fundið fyrir verk í hálsi auk verks í hnakka og baki nokkrum dögum áður, en eldri saga var um slíkt. Eiginmaður hafði farið til vinnu kl. 8 um morguninn, móðir hennar hringt í hana um kl. 9, en pá var hún á leiðinni með dóttur sína í leikskóla, en var „ekki sjálfri sér lík“. Pegar eiginmaðurinn hringdi svo í hana um kl. 11 svaraði hún ekki.

Við skoðun á bráðamóttöku kom í ljós að hún brást örlítið við sársaukaáreiti án pess að staðsetja pað og Glasgow Coma Scale-stig var metið 3/15. Ekki sáust kippir, ljósop voru pröng en svöruðu ljósi, vöðvaspenna var lítil. Sinaviðbrögð voru samhverf en daufari í ganglimum og báðar stóru tær fóru upp við iljastrok (jákvætt Babinski-teikn). Hún var barkaprædd fljótlega eftir komu. Engin merki voru um hnakkastífleika. Heilsufarssaga og skoðun voru að öðru leyti ómarkverðar fyrir utan stakar depilblæðingar vinstra megin á hálsi, 2 × $3 \mathrm{~cm}$ að stærð. Sjúklingur tók engin lyf að staðaldri.

Tölvusneið (TS) mynd af heila sýndi stórt drep hægra megin í litla heila/hnykli (cerebellum) (mynd 1 án skuggaefnis) og mikinn bjúg sem prengdi aðeins að fjórða heilahólfi. TS-myndataka sýndi lokun í efsta hluta botnslagæðar á um 12-13 mm löngum kafla. 

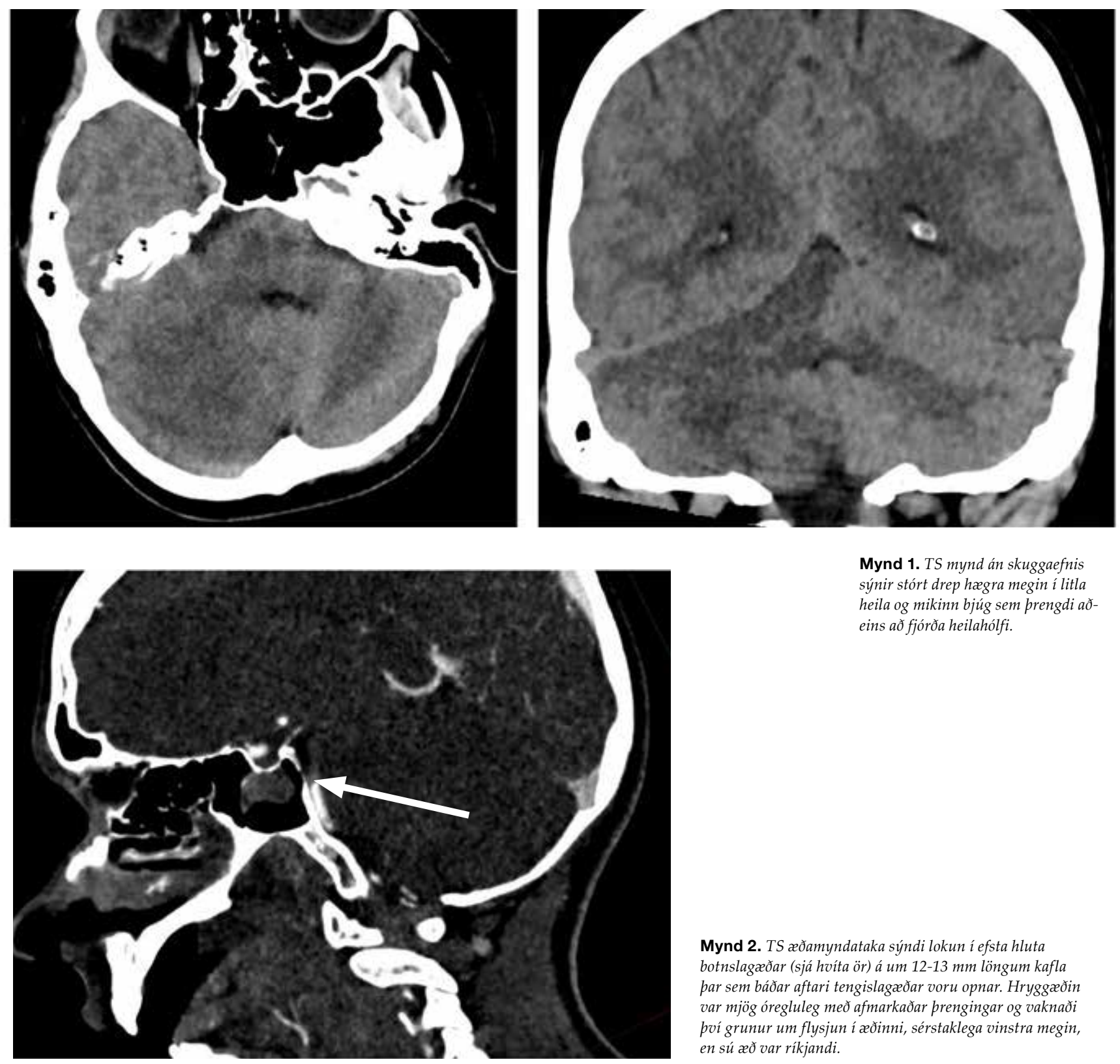

Mynd 1. TS mynd án skuggaefnis sýnir stórt drep hægra megin í litla heila og mikinn bjúg sem prengdi aðeins að fjórða heilahólfi.

Mynd 2. TS æðamyndataka sýndi lokun í efsta hluta botnslagæðar (sjá hvita ör) á um 12-13 mm löngum kafla par sem báðar aftari tengislagæðar voru opnar. Hryggæðin var miög óregluleg með afmarkaðar prengingar og vaknaði poí grunur um flysjun i æơinni, sérstaklega vinstra megin, en sú æð var ríkjandi.

Eðlileg fylling sást í aftari heilaslagæðum (PCA = Posterior Cerebral Artery) par sem báðar aftari tengislagæðar (P. Com. = Posterior Communicating Artery) voru opnar (mynd 2). Hryggslagæðin (VA = Vertebral Artery) var mjög óregluleg með afmarkaðar prengingar og vaknaði pví grunur um flysjun (dissection) í æðinni, sérstaklega vinstra megin, en sú æð var ríkjandi.

Í ljósi pessarar niðurstöðu var ákveðið að hefja segaleysandi meðferð með t-PA (tissue Plasminogen Activator). Hún fékk hleðsluskammt, en ekki var lokið við gjöf par sem ákveðið var að framkvæma segabrottnám. Talið var að einkennin hefðu staðið í 10-12 klukkustundir. Yfirleitt er pessi tími talinn of langur fyrir segaleysandi meðferð og blóðpurrðarslög í fremri blóðveitu, en talið er að heilastofn poli betur blóðpurrð. Í ljósi alvarleika var ákveðið að hefja segaleysandi meðferð.
Við æðamyndatöku sást óregla í hrygggangahluta vinstri hryggslagæðar sem staðfesti fyrri grun um flysjun (mynd 3a). Auðveldlega tókst að koma örlegg í gegnum flysjunarsvæðið. Inndæling í kjölfarið staðfesti lokun í fjarpriðjungi botnslagæðar (BA = Basilar Artery), en sogleggur var notaður einu sinni til að soga út sega úr botnslagæð sem tókst í fyrstu tilraun (mynd 3b). Við endurtekna æðamyndatöku kom í ljós að flæði var aftur komið á í BA auk eðlilegs blóðflæðis í báðum aftari heilaslagæðum gegnum aftari tengislagæð beggja vegna (mynd 3c). Örlítill randstæður segi sást í nær priðjungi botnslagæðar og var hann látinn eiga sig. Ekki er talið æskilegt að fjarlægja slíka sega pegar blóðflæði er til staðar, peir hreinsast oft við segaleysandi meðferð auk pess sem ekki voru merki um nýlegt drep á fyrstu mynd af höfði. Í lok rannsóknar sást einnig flysjun við V2 og V3 hluta á vinstri hryggslag- 

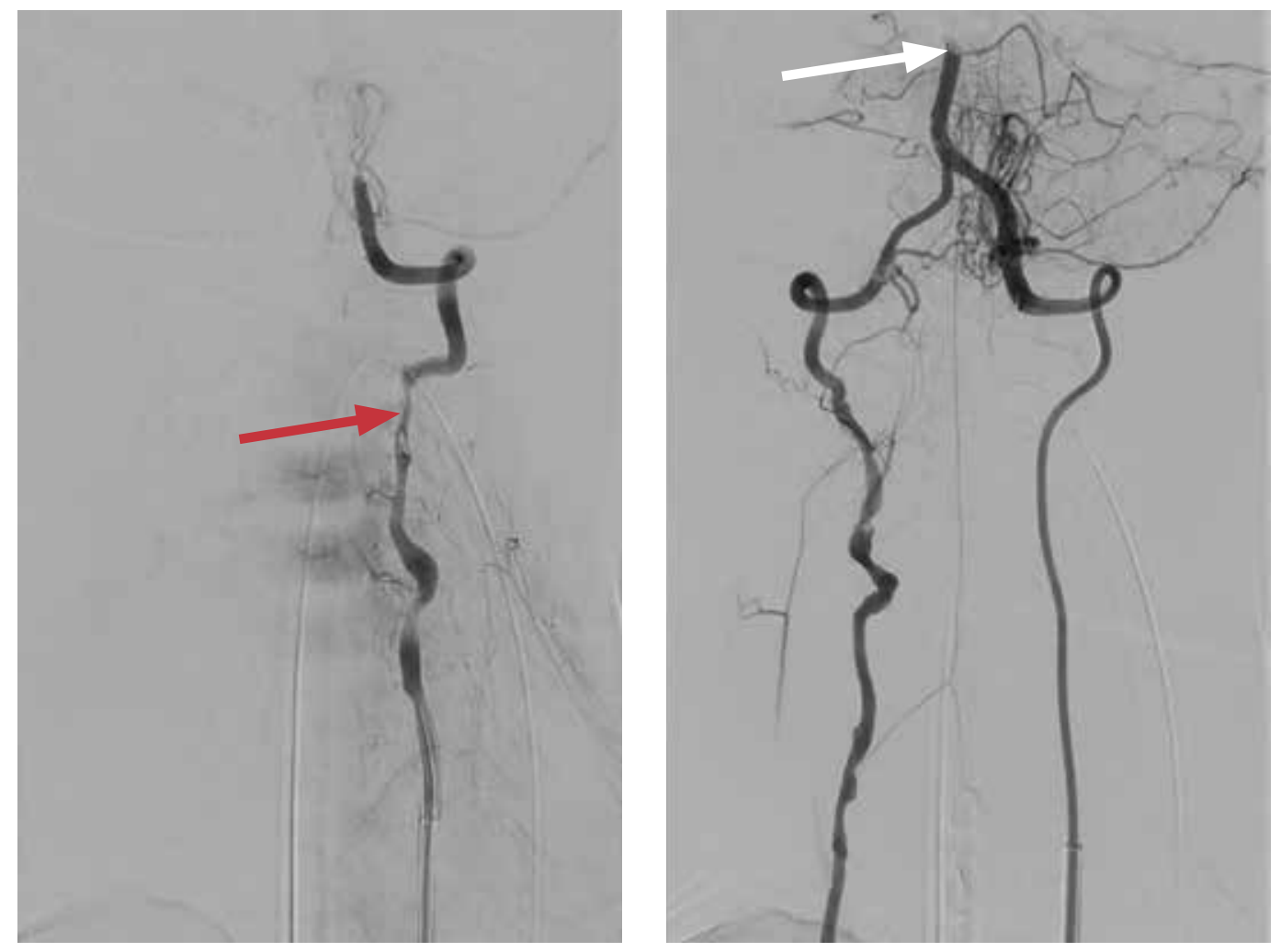

Mynd 3a. Æðamyndataka sýndi

lokun í efsta hluta botnslagæðar (sjá

hvíta ör) á um 12-13mm löngum kafla.

Hryggæðin var mjög óregluleg með afmarkaðar prengingar og staðfesti fyrri

grun um flysjun í æðinni (sjá rauða ör), sérstaklega vinstra megin, en sú æð var ríkjandi.

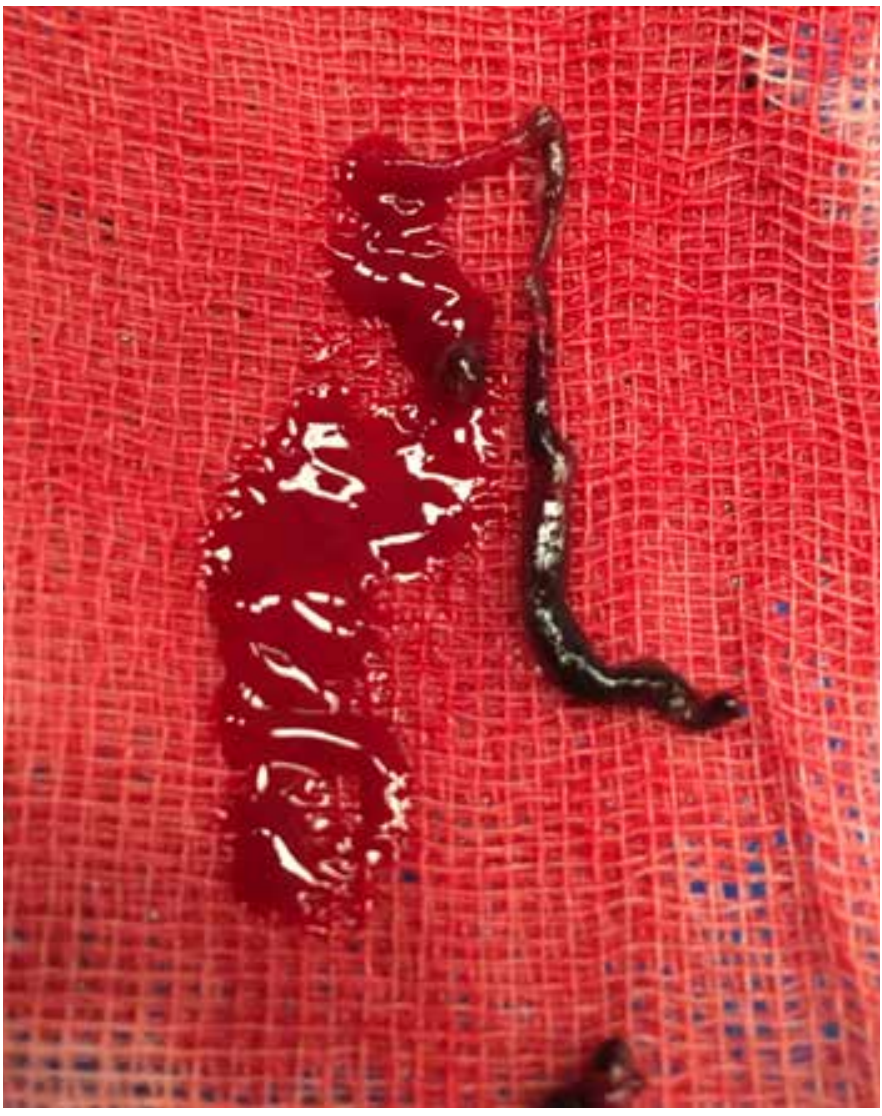

Mynd 3b. Segi sem fjarlægður var úr botnslagæð.

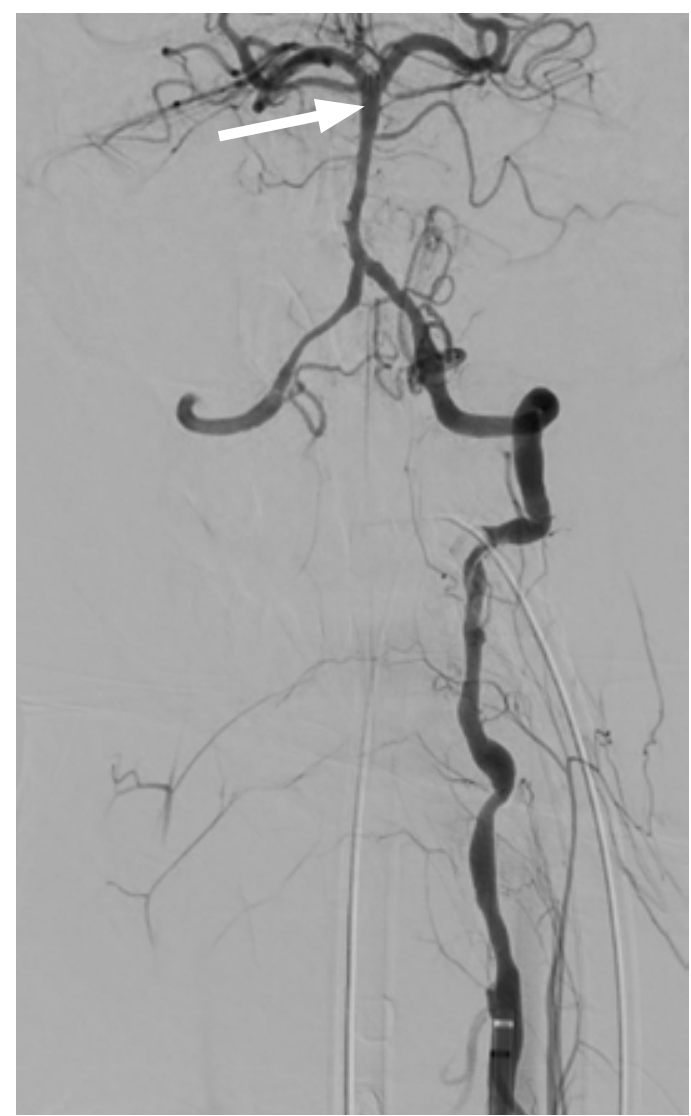

Mynd 3c. Við endurtekna æðamyndatöku eftir segabrottnám kom í ljós að flæði var aftur komið á í botnslagæð auk eðlilegs blódflæðis í bádum aftari heilaslagæðum (sjá ör). 

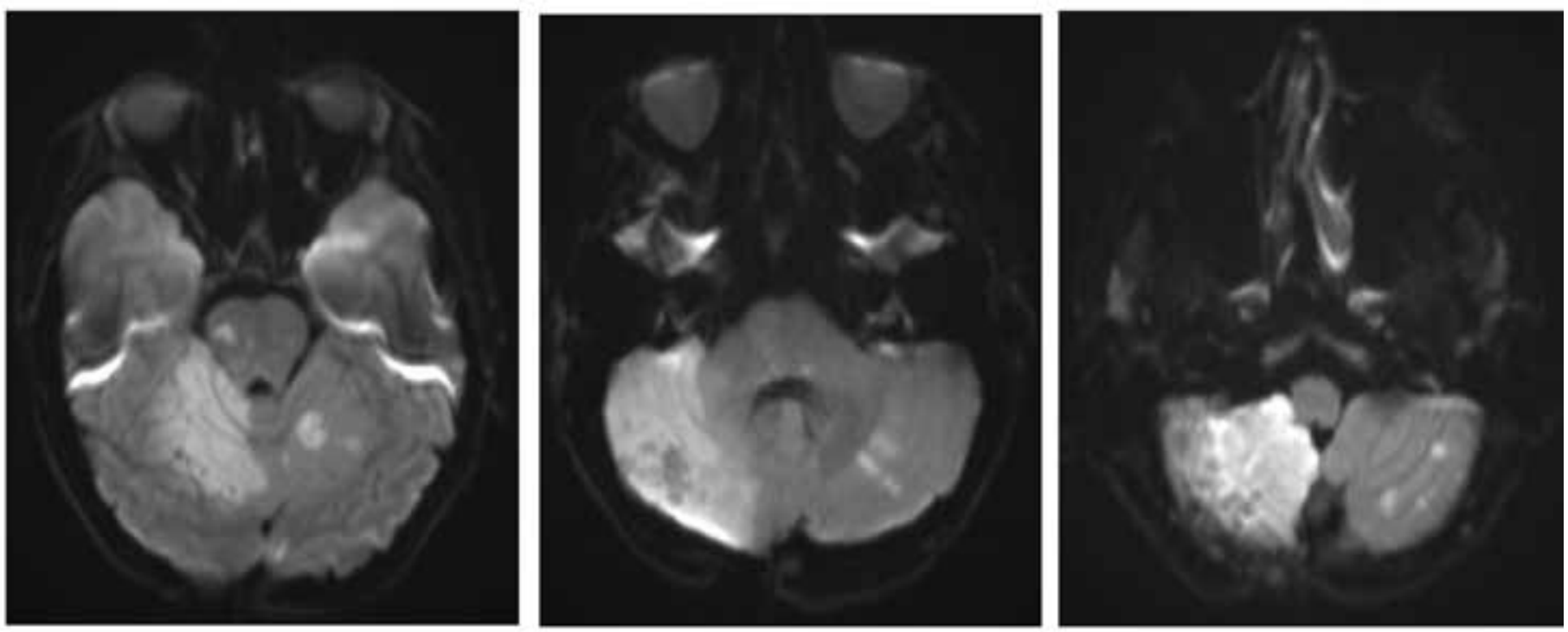

Mynd 4. SÓ af höfði (DWI) 12 dögum eftir upphaf einkenna sýndi útbreitt drep (segulskærar breytingar) i nær öllu hveli hægra litla heila auk ummerkja aðgerðar. Einnig sáust smærri og dreifð drep í vinstra hveli litla heila og merki um flekkótt drep í heilastofni við hægri legg litla heila og ummerkja lítils dreps í vinstri heilastúku.

æð sem ekki var meðhöndlað. Almennt er talið að ekki eigi að meðhöndla flysjanir ef blóðflæði er viðunandi.

TS-mynd af höfði var endurtekin premur klukkustundum eftir segabrottnám. Hún sýndi merki um stórt drep í hægra hveli litla heila sem hafði aukist. Mikill bjúgur með auknum rýmdaráhrifum var kominn fram. Ekki voru merki um hnykilspúfuhaulun (herniation). Einnig var grunur um að bjúgur væri í heilastofni, en erfitt var að meta slíkt á TS-mynd af höfði.

Fengin var ráðgjöf frá heila- og taugaskurðlækni. Í ljósi pess að konan var komin með illvígt drep í litla heila með auknum rýmdaráhrifum vegna dreps og bjúgs var ákveðið taka hana í aðgerð par sem hluti dreps í hægra litla heila var fjarlægt til pess að auka rými og verja heilastofninn. TS-mynd af höfði eftir aðgerð sýndi minni fyrirferð í aftari gróf og minni prýsting á fjórða heilahólf.

Mismunagreiningar til að byrja með voru meðal annars heilahimnubólga og eitranir. Hafin var meðferð með acýklóvír, og ceftríaxón, en gjöf var hætt fljótlega í kjölfar rannsókna og ráđgjafar smitsjúkdómalækna. Auk pess voru engin teikn um eitranir. Einnig höfðu verið vangaveltur um æðabólgu vegna útlits á myndum og var dexametasón gefið tímabundið. Hún var á gjörgæslu í um viku, en útskrifaðist paðan á deild.

Segulómskoðun af höfði 12 dögum eftir upphaf einkenna sýndi útbreitt drep í nær öllu hveli hægra litla heila auk ummerkja aðgerðar. Einnig sáust smærri og dreifð drep í vinstra hveli litla heila og merki um flekkótt drep í heilastofni við hægri legg litla heila (crus cerebelli) og ummerkja lítils dreps í vinstri heilastúku (thalamus) (mynd 4.)

Í kjölfar legu á heila- og taugaskurðdeild og taugadeild var sjúklingurinn útskrifuð á legudeild Grensáss og síðar á dagdeild til endurhæfingar. Gekk við lága göngugrind í fyrstu en sleppti henni síðar. Var áfram með óregluhreyfingu (ataxiu) í hægri hendi og notaði vinstri höndina meira en hægri. Starfræn geta sam- kvæmt endurbættum Rankin-kvarða ( $\mathrm{m}-\mathrm{RS}=$ modified Rankin Scale) 90 daga frá áfalli var metin 1. Meðferð með hjartamagnýl var síðar stöðvuð. Sjúkrapjálfun var haldið áfram í heimabæ eftir útskrift af Grensás.

\section{Klínískar myndir lokana í hrygg- og botnslagæðum heila}

Lokun í botn- og hryggslagæð (VB = Vertebro Basilar) hefur mönnum löngum verið hugleikið klínískt vandamál, en pví var fyrst lýst árið $1824 .{ }^{1}$ Í lok 19. aldar sýndi krufning á tveimur einstaklingum lokanir í BA af völdum sárasóttar, en einkenni höfðu byrjað skyndilega með helftar- og síðar fjór- og mænukylfulömun. Í byrjun 20. aldar voru pessi æðavandamál könnuð frekar, meðal annars með inndælingu litarefna í slagæðar sjúklinga sem höfðu látist. Greint var frá tveimur heilkennum. Annað var hjámiðlínu (paramedian) heilkenni brúar (pons) sem lýsti sér með einfaldri helftarlömun, en ef skemmd var beggja vegna með tvíhliða- eða fjórlömun. Hitt heilkennið var hliðlæga huldar (tegmentum) heilkennið sem olli krossaðri helftarlömun og skyntapi, en einkenni frá litla heila voru sömu megin og skemmd.

Ítarlegasta lýsing á lokun BA var sennilega frá 1932, en einkenni höfðu byrjað skyndilega með höfuðverk, sundli og pvoglumæli, á öðrum degi dái, vinstri helftarlömun og jákvæðu iljarstroki (tær fóru upp við prófun), síðar háum hita og dauða á fjórða degi. Sjaldgæft var að rétt greining væri sett meðan sjúklingar voru á lífi. Í rannsókn frá 1946 voru 11 af 18 sjúklingum með blóðsega í BA og 7 með segarek í BA. ${ }^{2}$ Lokun í botn- og hryggslagæð heila var talið mjög alvarlegt ástand og fylgdi pví mikil hætta á alvarlegri fötlun og dauða.

Um miðja 20 öld komust menn að pví að vandamálið var ekki bara einangrað við BA heldur tengdist einnig æðakölkunum í VA eða í báðum æðunum. ${ }^{3}$ Önnur æð sem tengdist drepi í heilastofni var aftari og neðri hnykilsslagæð (PICA = Posterior Inferior Cerebellar 
Artery), en einkenni samfara lokun pessarar æðar er oft nefnt Wallenberg-heilkenni (lýsing Wallenbergs birtist árið 1895) ${ }^{4}$ eða "lateral medullary syndrome“. Stífla í fyrrgreindri æð olli drepi í hlið- og bakhluta ólífukjarna (olivary nucleus) mænukylfu með mismiklum en dæmigerðum einkennum. ${ }^{5}$ Í rannsókn frá 1961 voru orsakir "lateral medullary syndroms“ kannaðar, en rannsóknin fann æðalokanir hjá 14 af 16 sjúklingum. Af peim voru 12 með lokun í VA og tveir með lokanir í PICA. Niðurstaðan kom heim og saman við aðrar rannsóknir pess tíma, en um 75\% sjúklinga með Wallenbergheilkenni voru með lokun í VA. ${ }^{5}$

Árið 1914 var fyrst rætt um tilvist skammvinnra blóðpurrðareinkenna sem undanfara slaga, eitthvað sem síðar var nefnt skammvinn heilablóðpurrð (TIA = Transient Ischemic Attack). Í rannsókn frá 1964 var könnuð áhætta TIA sem undanfara slaga í fremri og aftari blóðveitu. Rannsóknin var ekki stór, en niðurstaðan var að TIA í fremri blóðveitu væri hættulegri en í aftari. ${ }^{6}$ Árið 1966 kemur fram hugtakið lokað ástand (locked in). ${ }^{7}$ Áður fyrr var talið að algjör lokun í BA væri banvæn eða ylli mikilli fötlun. Rannsóknir sem lágu að baki pessu byggðu á niðurstöðum krufninga. Sama ár var birt rannsókn sem sýndi að ástandið var ekki alltaf banvænt ef góð hjáveita var til staðar. ${ }^{8}$ Árið 1977 birtist rannsókn par sem sýnt var fram á hversu flókið fyrirbærið er. ${ }^{9}$

\section{Meðferðarúrræði og æðamyndataka}

Lokanir í BV geta verið lífshættulegar. Vandamálið er hins vegar snúið og meðferðarúrræði skortir. Hugað var að notkun blóðpynningar við pessar kringumstæður, en fyrsta gjöf slíkrar meðferðar árið 1953 virtist skila góðum árangri. Árið 1955 voru birtar tvær greinar um notkun blóðpynningar við hótandi lokanir BA (ekki staðfest með æðamyndatöku). Bent var á að krufningar leiða sjaldan í ljós blæðingar tengdar stíflum í BA og oft sást að stíflur voru lagskiptar, en petta bendir til pær hafi myndast á löngum tíma.

Greining vandamálsins byggði á klínískum einkennum og voru allir sjúklingar alvarlega veikir. Blóðpynning samanstóð af heparini, tromexani og dicumaroli. Í fyrri rannsókninni voru 5 sjúklingar meðhöndlaðir. Hjá öllum gengu einkenni til baka pegar fullri blóðpynningu var náð. ${ }^{10}$ Í seinni rannsókninni voru 25 sjúklingar meðhöndlaðir. Í samanburðarhópi voru 23 sjúklingar sem ekki fengu blóðpynningu. Dánartíðni í hópnum sem fékk meðferð var $12 \%$ en $43 \%$ í hópnum sem fékk ekki blóðpynningu. Prír sjúklingar í meðferðarhópi létust, en hjá peim tókst ekki að ná fullri blóðpynningu. Hjá einum sjúklingi var blóðpynning hafin um svipað leyti og hann lést, hjá öðrum hófst blóðpynning 6 klukkustundum fyrir andlát og hjá peim priðja hafði blóðpynningarmeðferð verið rofin. ${ }^{11}$

Fyrsta æðamyndataka sem staðfesti lokun BA hjá lifandi sjúklingi var gerð árið $1956 .{ }^{12}$ Síðar kom í ljós að æðamyndatökur eru afar mikilvægar við greiningu, en eins og kemur fram í rannsókn frá 1973 valda lokanir í BA oft flókinni klínískri mynd. Í rannsókninni var gerð æðamyndataka hjá 9 einstaklingum með algjöra lokun á BA. Tími frá upphafi einkenna að æðamyndatöku var nokkrar klukkustundir upp í 10 ár. Í öllum tilvikum höfðu sjúklingar náð fullum bata frá upphaflegum einkennum. Prír voru með tímabundin einkenni sem höfðu varað í nokkrar vikur áður en æðamynd var gerð. Einn sjúklingur hafði farið í æðamyndatöku sama dag og hann missti meðvitund og lést. Algengustu einkennin voru breyting á meðvitund, svimi, óregluhreyfing, sundl, pvoglumæli, helftarmáttminnkun / -lömun og sjóntruflanir. Allir 9 sjúklingarnir fengu helftar máttminnkun / -lömun á einhverjum tímapunkti, 8 sjúklingar voru með talörðugleika og sjóntruflanir. Sjö kvörtuðu um svima og sundl. Hjá 7 af 9 kom lokun BA við æðamyndatöku hins vegar óvænt í ljós.

Á eftirfylgdartíma, sem var frá 5 mánuðum upp í 6 ár, voru allir sjúklingar á lífi með lítil brottfallseinkenni. Fyrir utan pann sem dó sama dag og æðamynd var gerð, dó annar premur vikum eftir æðamyndatöku en hann var með vaxandi einkenni og einn dó vegna heilahimnubólgu og heilaígerðar tveimur mánuðum eftir æðamyndatöku. ${ }^{13}$ Í rannsókn frá 1978 er bent á að lokanir í innrásar (intra ductal) hluta VA (V4) valdi um fjórðungi lokana í hálsslagæðum. Algengasta orsök er æðakölkun hjá fólki eftir sjötugt, en TIA sjást hjá um helmingi peirra. ${ }^{14}$

Árið 1982 birtist grein um notkun staðbundinnar segaleysandi meðferðar í slagæð (IA = Intra Arterial) hjá 27 ára konu með bráða BA-lokun. Einkenni löguðust hratt. ${ }^{15}$ Ári síðar birtist önnur grein um 5 sjúklinga sem fengu IA-meðferð vegna sega í VB. Par kom fram að segaleysandi meðferð í bláæð (IV = Intra Venous) kæmi sjaldan í veg fyrir dauðsföll. Prír af 5 sjúklingum, sem fengu staðbundna IA-meðferð náðu góðri opnun æðar og bata. ${ }^{16}$ Árið 1990 kom út grein yfir klíníska pætti BA-lokunar staðfesta með æðamyndatöku. Sagt var að með tilkomu staðbundinnar IA-segaleysandi meðferðar væri hugsanlegt að meðhöndla ástandið. Hins vegar vantaði upplýsingar um fyrirvaraeinkenni og teikn sem séu mikilvægar vísbendingar fyrir greiningu og meðferð. Reynt var að átta sig á gangi einkenna og staðsetningu lokana. Talið var að flestir peirra sem eru með bráða versnun einkenna væru með lokun í mið- og fjarhluta BA og að versnun stafaði af segareki frá VA-æð. Hins vegar purfi segarek í BA-æð ekki alltaf að lenda í fjarhluta æðarinnar heldur gæti hann fest fyrr í BA. ${ }^{17}$

Í grein frá 1992 kemur fram að IA-meðferð hafi verið stunduð frá 1987. Bent var á að t -PA var með meira næmi fyrir fibrini og með styttri helmingunartíma en urokinase (UK). Í rannsókninni var IA segaleysandi meðferð með UK borin saman við t-PA. Á pessum tíma höfðu 59 sjúklingar með bráðar lokarnir í VB og fremri blóðveitu heila verið meðhöndlaðir. Bent var á að tímafrekt getur reynst að reyna að enduropna æðar og vanalega hafi pað tekið um 120 mínútur. Hugsanleg skýring lélegs árangurs við t-PA 
gjöf væri að segi sé orðinn proskaður og leysist pví síður upp. IA-meðferð bætti klíníska útkomu við bráðar VB-lokanir og fækkaði dauðsföllum um 50\%. Verri horfur voru hjá sjúklingum með lokanir í fremri blóðveitu eða margar lokanir en góðar horfur ef lokunin var í nærhluta miðheilaslagæðar og hún stök. ${ }^{18}$

Árið 1995 birtist grein par sem IA-meðferð með UK og t-PA var borin saman við IV t-PA-meðferð. Enginn munur var á árangri UK eða t-PA hjá sjúklingum með MCA- og BA-lokanir en lélegri hjá sjúklingum með lokanir í innri hálsslagæð (ICA = Internal Carotid Artery). Góður árangur náðist pegar tókst að enduropna æð. Tíðni blæðinga var hins vegar há (28\%) og lést einn sjúklingur af völdum hennar. Horfur peirra sem fengu IV-meðferð voru lakari en hjá peim sem fengu IA-meðferð. ${ }^{19}$ Árið 1998 kom út grein par sem árangur IA-segaleysandi meðferðar með UK var metinn. Komist var að peirri niðurstöðu að IA-segaleysandi meðferð gagnist mest hjá sjúklingum með MCA- og BA-lokanir pegar upphafs NIHSS (National Institute of Health Stroke Scale) var undir 20 og meðferð var hafin innan fjögurra klukkustunda frá upphafi einkenna. ${ }^{20}$ Í grein frá 2002 kom í ljós að snemmíhlutun ( $\leq 6$ klukkustundir frá upphafi einkenna) við VB-lokanir leiddi til betri árangurs (BI = Barhtel Index $>90$ ) og sást hann hjá $36 \%$ miðað við $7 \%$ hjá peim sem fengu meðferð >6 klukkustundir. Dauðsföll í pessum hópum voru $52 \%$ í samanburði við 70\%. Beitt var IA-segaleysandi meðferð og hjá nokkrum voru restprengsli meðhöndluð með innæðablásningu (PTA = Percutaneous Tramsluminal Angioplasty). Fjögur mismunandi segaleysandi lyf voru notuð. ${ }^{21}$

Í grein frá 2003 sást að lágt NIHSS við komu og enduropnun æða spáði fyrir góðum horfum hjá sjúklingum með lokun í BA sem fengu IA-segaleysandi meðferð. Snemmíhlutun IA og að segi sást í BA á TS af höfði fylgdu auknar líkur á enduropnun. ${ }^{22}$ Aðrar rannsóknir sýna pað sama. ${ }^{23,24}$ Í grein frá 2006 par sem niðurstöður birtra greina um meðferð BA-lokana var kannaður kemur fram að enduropnun BA-lokana yrði í yfir helmingi peirra sem fá segaleysandi meðferð IV eða IA og um 45-55\% peirra sem fá slíka meðferð nái góðri færni eftir meðferð. Hins vegar sé vöntun á að veita slíka meðferð. ${ }^{23}$ Í annarri grein sama ár kom fram að um 15\% blóðpurrðarslaga séu í aftari blóðveitu. Horfur sjúklinga með einkenni slags í aftari blóðveitu og sega í BA er slæm og dánartíðni um $80 \%$.

Gerð var framskyggn slembirannsókn með IA UK sem var gefinn innan 24 klukkustunda frá upphafi einkenna hjá sjúklingum með staðfesta lokun. Góð útkoma sást hjá fjórum af 8 sem fengu IA UK en bara einum af 8 sem ekki fengu slíka meðferð. ${ }^{25}$ Ekki hafa verið gerðar fleiri framskyggnar slembirannsóknir. Hins vegar er í gangi BASICS (The Basilar Artery International Cooperation Study) rannsókn, en petta er fjölpjóða, fjölsetra opin priðja stigs slembirannsókn par sem kannað er öryggi IA og IV segaleysandi meðferðar við BA-lokun. Margar athyglisverðar niðurstöður hafa komið úr peirri rannsókn. Meginniðurstöður rannsókna benda hins vegar til mikilvægis snemmbærrar enduropnunar æða.

Mikilvægt er að benda á gagnsemi fjarheilbrigðispjónustu. Árið 2007 sýndi rannsókn að sjúklingum með BA-lokanir sem koma fyrst á dreifbýlissjúkrahús farnast verr en sjúklingum sem leggjast beint inn á sérhæfð sjúkrahús, vegna tafa á meðferð.

\section{Segabrottnám}

Segabrottnám er eitt mesta framfaraskref við meðferð bráðra blóðpurrðarslaga pegar segi hefur lokað æð. Gagnsemi segabrottnáms er vel staðfest við lokanir æða í fremri blóðveitu en engar slembirannsóknir eru til fyrir aftari blóðveitu. ${ }^{26}$ Árið 2008 var árangri mekanískrar innæðameðferðar par sem segi var fjarlægður með MERCI (Mechanical Embolus Removal in Cerebral Ischemia) tækni kynntur, en meðferðin náði til sjúklinga með VA- og PCA-lokanir. Meðferð var framkvæmd allt að 8 klukkustundum eftir upphaf einkenna. Enduropnun æða var staðfest hjá $78 \%$, dánartíðni var $44 \%$ og góðri færni (m-RS 0-2) náðu 22\% sjúklinga. Samanburðarhóp vantaði. ${ }^{27}$ Vegna pess hve horfur sjúklinga með lokun í botn og hryggjarslagæð eru slæmar og hversu segabrottnám getur verið árangursríkt er ekki hægt að réttlæta slembirannsóknir par sem segabrottnámi er ekki beitt.

\section{Kúpuopnun við̃ illvígu blóðpurrðarslagi}

Árið 1908 gerir Harvey Cushing sér grein fyrir að skurðaðgerð til að lækka prýsting innan höfuðkúpu vegna höfuðkúpubrots nýttist ekki eingöngu til að draga úr prýstingsáhrifum skemmda heldur gæti hún einnig dregið úr einkennum aukins innankúpuprýstings vegna heilabjúgs. ${ }^{28}$ Árið 1956 var vakin athygli á pví að líta megi á drep í heila líkt og stórt æxli sem valdi prýstingsáhrifum. ${ }^{29}$ Árið 1971 var bent á góðan árangur enniskúpuopnunar beggja vegna hjá völdum sjúklingum með áunninn heilaskaða. ${ }^{30}$ Síðla á sjötta og sjöunda áratugnum var sýnt fram á gagnsemi prýstingslækkandi (decompression) aðgerða og kallað var eftir frekari rannsóknum. Á 8. og 9 áratugnum höfðu myndgreiningar og gjörgæslumeðferð bætt meðferð slagsjúklinga og pví jókst áhugi á prýstingslækkandi skurðaðgerðum. ${ }^{31}$

Gerðar hafa verið nokkrar rannsóknir á skurðaðgerðum vegna dreps á svæði fremri blóðveitu, en lítið er um rannsóknir á aftari blóðveitu heila. Fyrstu rannsóknir á prýstingslækkandi skurðaðgerðum, gerðar fyrir árið 2000, gáfu innsýn í mikilvægi peirra. Litið var á einkenni og afdrif sjúklinga, aðallega sjúklinga með stór MCA-drep. Pessar rannsóknir lögðu grunninn að síðari slembirannsóknum. Svara purfti meðal annars spurningum um hvort nauðsynlegt væri að fjarlægja dauðan vef, hvort fylgjast ætti með innankúpuprýstingi og hvort skemmd væri í víkjandi eða ríkjandi heilahveli og hvort aldur skipti máli. Eftir 2000 voru gerðar slembirannsóknir á illvígu MCA-drepi í Evrópu. Par sem erfiðlega gekk að ná í sjúklinga með slík vandamál varð að taka rannsóknir saman til pess að fá tölfræðilega marktæka niðurstöðu. ${ }^{31}$

Prjár slembirannsóknir, DECIMAL, ${ }^{32}$ DESTINY $^{33}$ og HAMLET $^{34}$ könnuðu petta, auk rannsóknar sem kannaði árangur slíkrar meðferðar hjá eldri einstaklingum. ${ }^{35}$ Í safnarannsókn frá 2011 voru upplýsingar úr fyrrnefndum rannsóknum teknar saman. Niðurstaðan var að aðgerð innan 48 klukkustunda frá drepi dragi úr slæmri útkomu (m-RS 4-6), en heildaráhættuminnkun (HÁ) var $42 \%$ (95\% ÖB 23-56\%) og fjöldi til að ná árangri [NNT = Number Needed to Treat] var 2, (95\% ÖB 2-4) og HÁ fyrir dauðsföllum var 
50\% (95\% ÖB 32-64\%), NNT 2,(95\% ÖB 2-3). Aðgerð eftir 48 klukkustundir bar engan árangur. ${ }^{36}$

Skurðaðgerðir vegna dreps í litla heila eru á margan hátt flóknari en vegna dreps ofan tjalds (supratentorial). Ólíkt drepum í fremri blóðveitu er fátt um stórar og langtíma framskyggnar rannsóknir. Hins vegar eru margar rannsóknir sem gefa vísbendingar um gagnsemi neðanhnakka (suboccipital) kúpuopnunar með eða án brottnáms dreps í litla heila eða fráveitu heila- og mænuvökva (CSF drainage) til að draga úr dauðsföllum og bæta langtíma horfur illvígs dreps í litla heila. ${ }^{31}$ Árið 1956 var slíkum aðgerðum lýst hjá sjúklingum með minnkandi meðvitund vegna rýmdaraukandi dreps í litla heila, ${ }^{37,38}$ en pessari aðferð hafði lengi verið beitt til pess að draga úr lífshættulegum áhrifum bjúgs í svæði aftari blóðveitu, sem getur valdið prýstingi á heilastofn og vatnshöfði. Niðurstöður rannsóknar frá 1970 studdu notkun neðanhnakka kúpuopnana við drepi í aftari blóðveitu. ${ }^{39}$ Ekki hafa verið gerðar stórar slembirannsóknir á prýstingslækkandi skurðaðgerðum í aftari blóðveitu.

\section{Pakkir}

Pakkir til Önnu Bryndísar Einarsdóttur, en hún sinnti sjúklingi í bráðafasa veikinda og útvegaði okkur mynd af sega sem fjarlægður var í aðgerð.

\section{Heimildir}

1. Kingston PN. Case of Fatal Encephalitis with Hemiplegia, Immediately Excited by Cantharides, in Consequence of Intense Predisposition from Basilar and Internal Carotid Aneurisms. Edinb Med Surg J 1842; 57: 69-77.

2. Kubik CS, Adams RD. Occlusion of the basilar artery; a clinical and pathological study. Brain 1946; 69: 73-121.

3. Biemond A. Thrombosis of the basilar artery and the vascularization of the brain stem. Brain 1951; 74: 300-17.

4. Wallenberg A. Acute Bulbäraffection. (Embolie der Art. Cerebellar post. Ifn. sinstra.?) Arch f Psychiat $u$ Nevernheilk 1895; 27: 504.

5. Fisher CM, Karnes WE, Kubik CS. Lateral medullary infarction-the pattern of vascular occlusion. J Neuropathol Exp Neurol 1961; 20: 323-79.

6. Marshall J. The natural history of transient ischaemic cerebro-vascular Attacks. Q J Med 1964; 33: 309-24.

7. Plum F, Posner JB. [The diagnosis of stupor and coma]. Brain Nerve 2015; 67: 344-5.

8. Fields WS, Ratinov G, Weibel J, Campos RJ. Survival following basilar artery occlusion. Arch Neurol 1966; 15: 463-71.

9. Archer $\mathrm{CR}$, Horenstein S. Basilar artery occlusion: clinical and radiological correlation. Stroke 1977; 8: 383-90.

10. Millikan CH, Siekert RG, Shick RM. The use of anticoagulant drugs in the treatment of intermittent insufficiency and thrombosis within the basilar arterial system. Trans Am Neurol Assoc 1955-1956 (80 $0^{\text {th }}$ Meeting): 132-4.

11. Millikan $\mathrm{CH}$, Siekert RG, Shick RM. Studies in cerebrovascular disease. III. The use of anticoagulant drugs in the treatment of insufficiency or thrombosis within the basilar arterial system. Proc Staff Meet Mayo Clin 1955; 30 : 116-26.

12. Haugsted H. Occlusion of the basilar artery; diagnosis by vertebral angiography during life. Neurology 1956; 6: 8238.

13. Moscow NP, Newton TH. Angiographic implications in diagnosis and prognosis of basilar artery occlusion. Am J Roentgenol Radium Ther Nucl Med 1973; 119: 597-604.

14. Thompson JR, Simmons CR, Hasso AN, et al. Occlusion of the intradural vertebrobasilar artery. Neuroradiol 1978; 14: 219-29.

15. Zeumer H, Hacke W, Kolmann HL, et al. [Local fibrinolysis in basilar artery thrombosis (author's transl)]. Dtsch Med Wochenschr 1982; 107: 728-31.
16. Zeumer H, Hacke W, Ringelstein EB. Local intraarterial thrombolysis in vertebrobasilar thromboembolic disease. AJNR Am J Neuroradiol 1983; 4: 401-4.

17. Ferbert A, Bruckmann H, Drummen R. Clinical features of proven basilar artery occlusion. Stroke 1990; 21: 1135-42.

18. Zeumer H, Freitag HJ, Zanella F, et al. Local intra-arterial fibrinolytic therapy in patients with stroke: urokinase versus recombinant tissue plasminogen activator (r-TPA). Neuroradiol 1993; 35: 159-62.

19. Sasaki O, Takeuchi S, Koike T, et al. Fibrinolytic therapy for acute embolic stroke: intravenous, intracarotid, and intra-arterial local approaches. Neurosurg 1995; 36: $246-$ 52; discussion 52-3.

20. Gonner F, Remonda L, Mattle H, et al. Local intra-arterial thrombolysis in acute ischemic stroke. Stroke 1998; 29: 1894-900.

21. Eckert B, Kucinski T, Pfeiffer G, et al. Endovascular therapy of acute vertebrobasilar occlusion: early treatment onset as the most important factor. Cerebrovasc Dis 2002; 14: $42-50$.

22. Arnold M, Nedeltchev K, Schroth G, et al. Clinical and radiological predictors of recanalisation and outcome of 40 patients with acute basilar artery occlusion treated with intra-arterial thrombolysis. J Neurol Neurosurg Psychiatry 2004; 75: 857-62.

23. Lindsberg PJ, Mattle HP. Therapy of basilar artery occlusion: a systematic analysis comparing intra-arterial and intravenous thrombolysis. Stroke 2006; 37: 922-8.

24. Schonewille WJ, Algra A, Serena J, et al. Outcome in patients with basilar artery occlusion treated conventionally. J Neurol Neurosurg Psychiatry 2005; 76: 1238-41.

25. Macleod MR, Davis SM, Mitchell PJ, et al. Results of a multicentre, randomised controlled trial of intra-arterial urokinase in the treatment of acute posterior circulation ischaemic stroke. Cerebrovasc Dis 2005; 20: 12-7.

26. Sigurðsson AP. Yfirlitsgrein. Segabrottnám við brátt blóðpurrðarslag. Læknablaðið 2018; 104: 19-26.

27. Lutsep HL, Rymer MM, Nesbit GM. Vertebrobasilar revascularization rates and outcomes in the MERCI and multi-MERCI trials. J Stroke Cerebrovasc Dis 2008; 17: 55-7.

28. Cushing H. I. Subtemporal Decompressive Operations for the Intracranial Complications Associated with Bursting Fractures of the Skull. Ann Surg 1908; 47: 641-4.1.
29. Scarcella G. Encephalomalacia simulating the clinical and radiological aspects of brain tumor; a report of 6 cases. J Neurosurg 1956; 13: 278-92.

30. Kjellberg RN, Prieto A, Jr. Bifrontal decompressive craniotomy for massive cerebral edema. J Neurosurg 1971; 34: 488-93.

31. Agarwalla PK, Stapleton CJ, Ogilvy CS. Craniectomy in acute ischemic stroke. Neurosurg 2014; 74 Suppl 1: S15162.

32. Vahedi K, Vicaut E, Mateo J, et al. Sequential-design, multicenter, randomized, controlled trial of early decompressive craniectomy in malignant middle cerebral artery infarction (DECIMAL Trial). Stroke 2007; 38: 2506-17.

33. Juttler E, Schwab S, Schmiedek P, et al. Decompressive Surgery for the Treatment of Malignant Infarction of the Middle Cerebral Artery (DESTINY): a randomized, controlled trial. Stroke 2007; 38: 2518-25.

34. Hofmeijer J, Kappelle LJ, Algra A, et al. Surgical decompression for space-occupying cerebral infarction (the Hemicraniectomy After Middle Cerebral Artery infarction with Life-threatening Edema Trial [HAMLET]): a multicentre, open, randomised trial. Lancet Neurol 2009; 8: 326-33.

35. Zhao J, Su YY, Zhang Y, et al. Decompressive hemicraniectomy in malignant middle cerebral artery infarct: a randomized controlled trial enrolling patients up to 80 years old. Neurocrit Care 2012; 17: 161-71.

36. Starling AJ, Wellik KE, Hoffman Snyder CR, et al. Surgical decompression improves mortality and morbidity after large territory acute cerebral infarction: a critically appraised topic. Neurologist 2011; 17: 63-6.

37. Lindgren SO. Infarctions simulating brain tumours in the posterior fossa. J Neurosurg 1956; 13: 575-81.

38. Fairburn B, Oliver LC. Cerebellar softening; a surgical emergency. BMJ 1956; 1: 1335-6.

39. Lehrich JR, Winkler GF, Ojemann RG. Cerebellar infarction with brain stem compression. Diagnosis and surgical treatment. Arch Neurol 1970; 22: 490-8. 


\section{Occlusion of the vertebrobasilar artery. Case presentation and literature review}

Albert Páll Sigurðsson ${ }^{1}$

Porsteinn Gunnarsson ${ }^{2,3}$ Hjalti Már Pórisson ${ }^{3}$ Ingvar Hákon Ólafsson ${ }^{4}$ Gunnar Björn Gunnarsson ${ }^{5}$

\author{
This paper is a case report of a 22 year old, previously healthy \\ woman that presented comatose to the Emergency Room \\ at Landspitali University Hospital Iceland. A CT image of the \\ head on admission revealed a large right cerebellar infarct \\ with oedema compressing the fourth ventricle. A CT ang- \\ logram on admission was suspicious for a dissection of the \\ left vertebral artery (confirmed during endovascular treatment) \\ and a total occlusion of the distal third of the basilar artery. \\ Thrombolytic therapy with t-PA was initiated followed by \\ thrombectomy with good recanalization. The following day
}

the patient underwent suboccipital craniotomy for malignant cerebellar infarction. She made a good clinical recovery to a modified Ranking scale of 1 at 90 days after discharge from the hospital. Following the case is a literature review on the clinical aspects of occlusion of the vertebrobasilar system, use and utility of imaging and treatment with (anticoagulation, V and IA thrombolysis) modalities that have been tried. Finally, the evidence regarding thrombectomy and the role of craniotomy for malignant stroke are reviewed.

${ }^{1}$ Dep. of Neurology Landspitali University Hospital Iceland, ${ }^{2}$ Dep. of Radiology Sahlgrenska University Hospital, Gothenburg, Sweden, ${ }^{3}$ Dep. of Interventional Radiology University, Hospital Iceland, ${ }^{4} \mathrm{Dep}$. of Neurosurgery University Hospital Iceland ${ }^{5} \mathrm{Dep}$. of Rehabilitation Landspitali University Hospital Iceland.

Key words: Vertebrobasilar occlusion, angiogram, anticoagulation, information from an prospective open trial, IV and IA thrombolysis, thrombectomy, Telemedicine and Craniotomy for malignant stroke.

\section{Xarelto 15 mg og 20 mg filmuhúðaðar töflur - Skyldutexti}

$\nabla$ Petta lyf er undir sérstöku eftirliti til að nýjar upplýsingar um öryggi lyfsins komist fljótt og örugglega til skila. Tilkynna skal Lyfjastofnun um allar aukaverkanir sem grunur er um að tengist lyfinu. Virkt efni: Rivaroxaban. Ábendingar: Fyrirbyggjandi meðferð gegn heilaslagi og segareki hjá fullorðnum sjúklingum með gáttatif án lokusjúkdóms og einn eða fleiri áhættupætti, svo sem hjartabilun, háprýsting, aldur $\geq 75$ ára, sykursýki, sögu um heilaslag eða skammvinnt blóðpurrðarkast. Meðferð við segamyndun í djúplægum bláæðum og segareki í lungum og til að fyrirbyggja endurtekna segamyndun í djúplægum bláæðum og segarek í lungum hjá fullorðnum. Frábendingar: •Ofnæmi fyrir virka efninu eđa einhverju hjálparefnanna. •Virk blæđing sem hefur klíníska pýðingu. •Áverki eđa ástand par sem talið er að hætta geti verið á mikilli blæðingu. Um getur verið að ræða sár sem er eða hefur nýlega verið í meltingarvegi, illkynja æxli par sem mikil hætta er á blæðingu, nýlegan áverka á heila eđa mænu, nýlega aðgerð á heila, mænu eða auga, nýlega innankúpublæðingu, pekkta æðahnúta í vélinda eða grun um slíkt, missmíði slag- og bláæðatenginga, æðagúlp, eða mjög afbrigðilegar æðar í mænu eða heila. •Samhliða meðferð með öðrum segavarnarlyfjum, t.d. ósundurgreindu (unfractionated) heparíni, léttu (low molecular weight) heparíni (enoxaparin, dalteparin o.s.frv.), heparín afleiðum (t.d. fondaparinux), segavarnarlyfjum til inntöku (warfarín, dabigatran etexilat, apixaban o.s.frv.), nema við pær sérstöku aðstæður að verið sé að skipta um blóðpynningarmeðferð eða ef ósundurgreint heparín er gefið í skömmtum sem duga til að viðhalda opnum æðalegg í miðlægri bláæð eða slagæð. • Lifrarsjúkdómur með blóðstorkutruflunum og blæðingarhættu sem hefur klíníska pýðingu par með talið hjá sjúklingum með skorpulifur af flokki Child Pugh B og C. • Meðganga og brjóstagjöf. Markaðsleyfishafi: Bayer AG. Heimild: Unnið í nóvember 2019 úr Samantekt á eiginleikum lyfs (október 2019). Nálgast má upplýsingar um lyfið og samantekt á eiginleikum pess, fylgiseðil, verð og greiðslupátttöku á vef Lyfjastofnunar, www.serlyfjaskra.is. Vinsamlegast kynnið ykkur fræðsluefni ætlað læknum og sjúklingum áður en meðferð lyfsins hefst. Afhenda skal öllum sjúklingum öryggiskort áður en meðferð er hafin. Vinsamlegast hafið samband við umboðsaðila lyfsins (Icepharma hf.) í síma 5408000 ef óskað er eftir fræðsluefni fyrir lyfið.

BAY191101 